\title{
Equol enhances tamoxifen's anti-tumor activity by induction of caspase-mediated apoptosis in MCF-7 breast cancer cells
}

\author{
Christiana Charalambous, Chara A Pitta and Andreas I Constantinou*
}

\begin{abstract}
Background: Soy phytoestrogens, such as daidzein and its metabolite equol, have been proposed to be responsible for the low breast cancer rate in Asian women. Since the majority of estrogen receptor positive breast cancer patients are treated with tamoxifen, the basic objective of this study is to determine whether equol enhances tamoxifen's anti-tumor effect, and to identify the molecular mechanisms involved.

Methods: For this purpose, we examined the individual and combined effects of equol and tamoxifen on the estrogen-dependent MCF-7 breast cancer cells using viability assays, annexin-V/PI staining, cell cycle and western blot analysis.

Results: We found that equol $(>50 \mu \mathrm{M})$ and 4-hydroxy-tamoxifen $(4-\mathrm{OHT} ;>100 \mathrm{nM})$ significantly reduced the MCF-7 cell viability. Furthermore, the combination of equol $(100 \mu \mathrm{M})$ and 4-OHT $(10 \mu \mathrm{M})$ induced apoptosis more effectively than each compound alone. Subsequent treatment of MCF-7 cells with the pan-caspase inhibitor Z-VADFMK inhibited equol- and 4-OHT-mediated apoptosis, which was accompanied by PARP and a-fodrin cleavage, indicating that apoptosis is mainly caspase-mediated. These compounds also induced a marked reduction in the bcl-2:bax ratio, which was accompanied by caspase- 9 and caspase-7 activation and cytochrome-c release to the cytosol. Taken together, these data support the notion that the combination of equol and tamoxifen activates the intrinsic apoptotic pathway more efficiently than each compound alone.
\end{abstract}

Conclusions: Consequently, equol may be used therapeutically in combination treatments and clinical studies to enhance tamoxifen's effect by providing additional protection against estrogen-responsive breast cancers.

Keywords: Apoptosis, Breast cancer, Caspases, Equol, Tamoxifen

\section{Background}

Evidence from epidemiological studies suggest that nutrition plays an important role in the development of breast cancer, which remains the most common malignancy and the second most lethal cancer in women worldwide [1-4]. It was observed that the incidence of breast cancer is much lower in Asian women compared to Western women, and this was attributed to the daily consumption of soy products by Asian women, which contain phytoestrogens [5]. Equol (7-hydroxy3-(4'-hydroxyphenyl)-chroman) is the bioactive metabolite of daidzein, a major phytoestrogen found in soy

\footnotetext{
*Correspondence: andreasc@ucy.ac.cy

Department of Biological Sciences, University of Cyprus, 75 Kallipoleos str, PO box 20537, Lefkosia 1678, Cyprus
}

(c) 2013 Charalambous et al.; licensee BioMed Central Ltd. This is an Open Access article distributed under the terms of the

products. Recent studies suggest that equol has the greatest in vitro bioactivity and anti-oxidant activity when compared to soy isoflavones [6-8]. As known, 30$50 \%$ of the adult population cannot metabolize daidzein to equol and, interestingly, clinical response is usually limited to people who are "equol producers" $[9,10]$. Equol is reported to bind to both estrogen receptors $E R \alpha$ and $E R \beta$, with a higher binding affinity for $E R \beta$, which has been implicated in the inhibition of proliferation and induction of apoptosis in breast cancer cells [8,11-13]. Previous studies suggest that equol induces apoptosis in the ER negative breast cancer cells $[14,15]$, while it seems to have a biphasic effect in ER-positive breast cancer cells enhancing cell proliferation at low concentrations $(<10 \mu \mathrm{M})$ [15-18] and possibly exerting 
an inhibitory effect at high concentrations (50-100 $\mu \mathrm{M})$ [14]. As the role of equol in relation to breast cancer remains unclear, this study was designed to delineate the effect of equol on estrogen-dependent breast cancer cells using MCF-7 cells as a model system. This is particularly important as the controversy of results obtained in the soy isoflavone human intervention studies and the inability to establish the beneficial effects of soy isoflavones could be attributed to the failure to distinguish between "equol producers" and "non-equol producers" $[10,19]$. Therefore, the significance of evaluating the therapeutic potential of equol becomes more evident and may facilitate the design and implementation of future equol intervention studies for cancer.

Several reports suggest that equol and daidzein induce cell cycle arrest and apoptosis in breast cancer cells $[2,8,14,20-25]$. More specifically, it has been recently shown that daidzein induces MCF-7 breast cancer cell apoptosis via the intrinsic (mitochondrial) caspasedependent apoptotic pathway [2]. However, the biological effects of equol have not been investigated as well as those of daidzein. Therefore, the aim of this study is to thoroughly explore the mechanism of equolmediated apoptosis.

Tamoxifen, on the other hand, is an ER $\alpha$ antagonist classified as a non-steroidal selective estrogen receptor modulator (SERM), widely used in cancer chemoprevention and chemotherapy to prevent primary breast tumors or the development of recurrences, respectively [26-28]. Tamoxifen, and its bioactive metabolite 4-hydroxy-tamoxifen (4-OHT), inhibit proliferation and induce apoptosis in several types of ER-positive and ER-negative breast cancer cells, rat mammary tumors and other cancer types [29-34]. However, the anti-tumor mechanism of tamoxifen is not yet completely understood.

Accumulating experimental evidence from in vivo studies is beginning to support the possibility that soy components may enhance tamoxifen's anti-tumor effect, by providing stronger protection against mammary carcinogenesis than tamoxifen alone [35,36]. Moreover, we have previously identified daidzein as the soy ingredient enhancing tamoxifen's ability to prevent rat mammary tumor formation [37]. Since equol is the bioactive metabolite of daidzein [38,39], these findings support the premise that equol may potentiate tamoxifen's efficacy against mammary carcinogenesis. We are reporting here the mechanism by which this daidzein metabolite enhances tamoxifen's anti-tumor activity in ER positive breast cancer cells.

\section{Methods}

\section{Cell culture}

MCF-7 breast cancer cell line (obtained from ATCC) was cultured in MEM supplemented with $10 \%$ fetal bovine serum (FBS), 1\% antibiotic-antimycotic, $1 \mathrm{mM}$ sodium pyruvate, $1 \%$ non-essential aminoacids (MEMNEAA), 2 mM L-glutamine (Gibco, Life Technologies, Paisley, UK) and $0.06 \mu \mathrm{g} / \mathrm{ml}$ insulin (Sigma, St. Louis, MI, USA). They were incubated at $37^{\circ} \mathrm{C}$ in a humidified incubator with $5 \% \mathrm{CO}_{2}$. For estrogen deprivation, three days before treatment with equol or tamoxifen, cells were cultured in phenol-red free MEM supplemented with $10 \%$ dextran-coated charcoal (DCC) - treated FBS, $1 \%$ antibiotic-antimycotic, $1 \%$ non-essential aminoacids, $2 \mathrm{mM}$ L-glutamine, $1 \mathrm{mM}$ sodium pyruvate and $0.06 \mu \mathrm{g} /$ $\mathrm{ml}$ insulin [40].

\section{Antibodies and reagents}

Equol and 4-OHT were purchased from LC laboratories (Woburn, MA, USA) and Alexis Biochemicals (Enzo Life Sciences, Lausen, Switzerland), respectively. Reagents also included the pan-caspase inhibitor Z-VAD-FMK (Calbiochem, Nottingham, UK) and the MTT reagent (Sigma, St. Louis, MI, USA). The bcl-2, bax, glyceraldehyde 3-phosphate dehydrogenase (GAPDH) and cyclooxygenase-4 (COX-4) antibodies were purchased from Santa Cruz Biotechnology (Heidelberg, Germany) whereas the poly-(ADP ribose)-polymerase-1 (PARP-1), $\alpha$-fodrin, caspase- 9 , caspase- 8 , caspase- 7 , caspase- 6 , cytochrome-c, and $\alpha$-tubulin antibodies were purchased from Cell Signaling Technology (Danvers, MA, USA).

\section{MTT assay}

The effect of equol, 4-OHT and their combination on MCF-7 viability was examined using the MTT (monotetrazolium) assay [41]. The cells were plated in 96-well plates $\left(3 \times 10^{3}\right.$ cells/well) and treated with different concentrations of equol and 4-OHT for 24, 48 and $72 \mathrm{~h}$. The MTT reagent was subsequently added (1:10 dilution) for $4 \mathrm{~h}$ at $37^{\circ} \mathrm{C}$. The media were then removed and DMSO $(150 \mu \mathrm{L} /$ well $)$ was added for $20 \mathrm{~min}$. The absorbance, measured at $570 \mathrm{~nm}$, was proportional to the number of viable cells per well.

\section{Mitochondrial/cytosolic extract preparation}

Cells were cultured in 150-mm Petri dishes and treated for $48 \mathrm{~h}$ with vehicle control (DMSO and ethanol), equol $(100 \mu \mathrm{M})$, 4-OHT $(10 \mu \mathrm{M})$ or their combination. Mitochondrial and cytosolic extracts were prepared using the mitochondrial/cytosol fractionation kit (Abcam, UK).

\section{Western blot analysis}

MCF-7 cells were treated with equol $(100 \mu \mathrm{M})$, 4-OHT $(10 \mu \mathrm{M})$ and their combination for $48 \mathrm{~h}$, with or without Z-VAD-FMK $(20 \mu \mathrm{M})$, and whole cell or mitochondrial/ cytosolic extracts were prepared as previously described [42]. Protein content in the extracts was quantified using a bicinchoninic acid (BCA) protein assay kit (Pierce, 

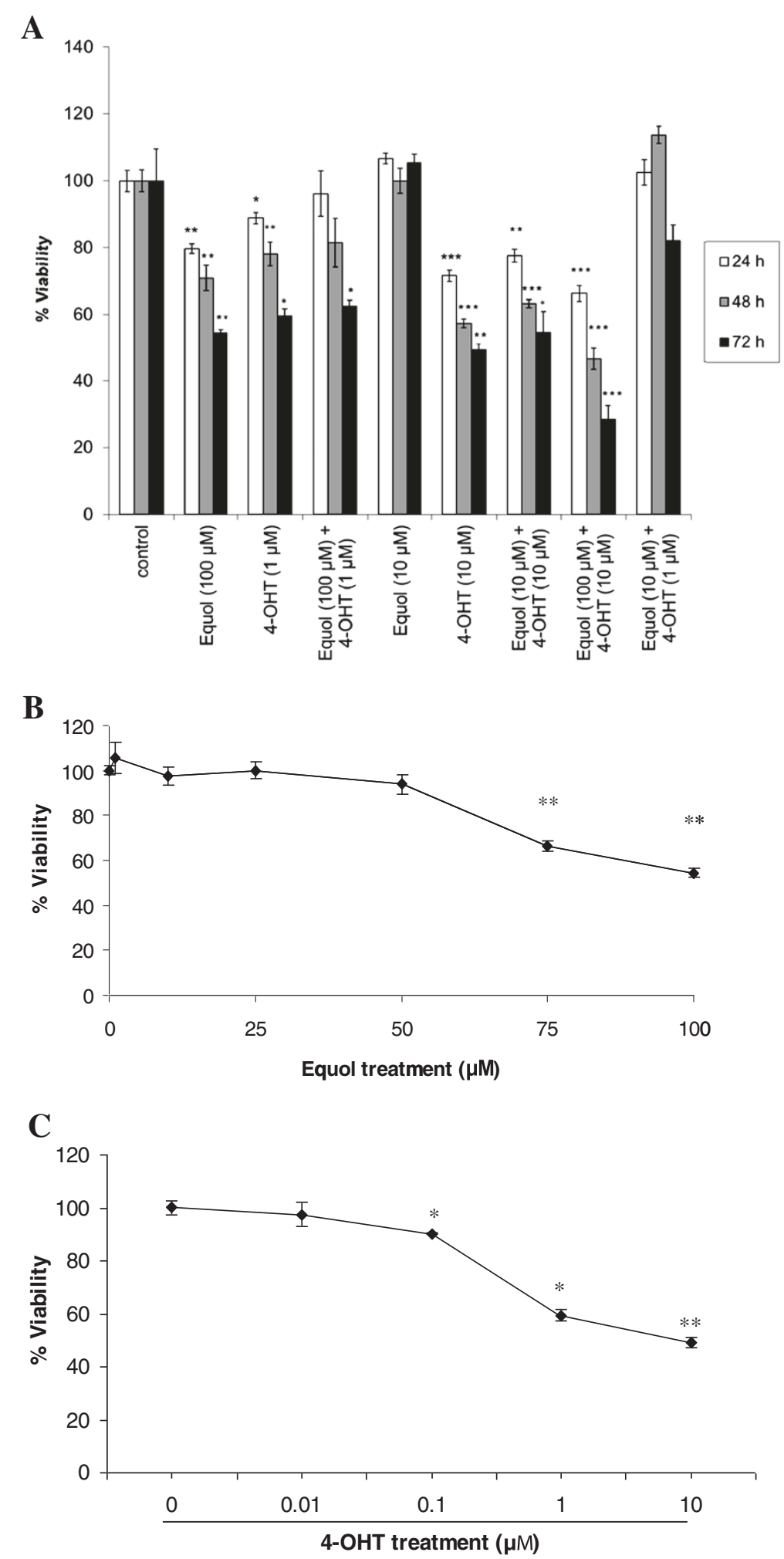

Figure 1 (See legend on next page.) 


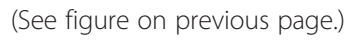

Germany). Equal amounts of proteins $(40 \mu \mathrm{g} / \mathrm{lane})$ were separated on SDS-PAGE and electrotransferred to $0.45 \mu \mathrm{m}$ nitrocellulose membranes. The membranes were then blocked with $5 \%$ non-fat dry milk in TBST (Tris buffered saline supplemented with $0.1 \%$ Tween-20) and probed with antibodies against PARP-1 (1:1000 dilution), $\alpha$-fodrin (1:500 dilution), caspase-9 (1:500 dilution), caspase-8 (1:500 dilution), caspase-7 (1:500 dilution), caspase-6 (1:500 dilution), GAPDH (1:1000 dilution), bcl-2 (1:500 dilution), bax (1:500 dilution), COX-4 (1:250 dilution), cytochrome-c (1:250 dilution), and $\alpha$-tubulin (1:1000 dilution) followed by HRPconjugated anti-rabbit or anti-mouse immunoglobulin-G (IgG; 1:2000 dilution). Protein bands were detected by chemiluminescence using the Luminol substrate (Santa Cruz) according to the manufacturer's protocol and analyzed using the UVP bioimaging system (Cambridge, UK).

\section{Cell death ELISA (Enzyme-linked immunosorbent assay)}

MCF-7 cells were plated in 96-well plates in quadruplicates at a concentration of $3 \times 10^{4}$ cells $/ \mathrm{ml}(100 \mu \mathrm{l} /$ well $)$. Cells were treated with equol $(100 \mu \mathrm{M}), 4-\mathrm{OHT}(10 \mu \mathrm{M})$ and their combination and lysed after $72 \mathrm{~h}$. Lysates were analyzed for the presence of nucleosomes using the Cell Death Detection ELISA Plus kit (Roche Diagnostics, Mannheim, Germany). Absorbance, measured at $405 \mathrm{~nm}$, was proportional to cell death.

\section{Tali $^{\mathrm{TM}}$ apoptosis kit}

Cells were plated in 60-mm plates and treated with equol $(100 \mu \mathrm{M}), 4-\mathrm{OHT}(10 \mu \mathrm{M})$ and their combination, with or without Z-VAD-FMK $(20 \mu \mathrm{M})$. Cells were harvested $72 \mathrm{~h}$ post-treatment and stained using annexin-V Alexa Fluor ${ }^{\circledR}$ 488/PI (propidium iodide), as described by the Tali ${ }^{\mathrm{mx}}$ apoptosis kit (Life Technologies). Cell viability, death and apoptosis were evaluated using the $\mathrm{Tali}^{\mathrm{Tm}}$ Image-based Cytometer (Life Technologies). The annexin-V positive/PI negative cells were recognized as apoptotic cells by the cytometer software whereas the annexin $\mathrm{V}$ positive/PI positive cells were identified as dead cells. Similarly, the annexin V-negative/PI negative cells were identified as viable cells.

\section{Cell cycle analysis}

Cells were plated in $100-\mathrm{mm}$ plates and treated with equol $(100 \mu \mathrm{M})$, 4-OHT $(10 \mu \mathrm{M})$, and their combination for $6,12,24,48$ and $72 \mathrm{~h}$. They were harvested, fixed in $70 \%$ ethanol, incubated with the PI staining solution (containing $1 \mathrm{mg} / \mathrm{ml}$ PI and $100 \mu \mathrm{g} / \mathrm{ml}$ RNase) for $15 \mathrm{~min}$ at $37^{\circ} \mathrm{C}$ and analyzed for DNA content using the Guava EasyCyte $^{\text {tu }}$ flow cytometer and the GuavaSoft analysis software (Millipore, Watford,UK).

\section{Statistical analysis}

Values are presented as the mean \pm SEM. Statistical significance was evaluated using student's t-test for paired comparison. $P<0.05$ was considered statistically significant. Data are representative of three individual experiments. Each experimental group was repeated in triplicates or quadruplicates, as described in the Figure Legends section.

\section{Results}

\section{Equol and 4-OHT reduce MCF-7 viability}

To examine the ability of equol and 4-OHT to inhibit MCF-7 cell growth, their individual and combined effects on cell viability were observed. Equol $(>50 \mu \mathrm{M})$ and 4-OHT ( $>100 \mathrm{nM})$ provoked a marked reduction in MCF-7 viability in a dose- and time-dependent manner (Figure 1A-C). In contrast, lower concentrations of equol $(1 \mathrm{nM}-1 \mu \mathrm{M})$ did not exert a significant effect on cell growth (data not shown). Futhermore, the combination of equol $(100 \mu \mathrm{M})$ and 4-OHT $(10 \mu \mathrm{M})$ reduced cell viability in an additive manner (72 h; Figure 1A), suggesting that equol enhances tamoxifen's anti-proliferative effect in MCF-7 cells.

\section{Equol and 4-OHT induce MCF-7 cell death via apoptosis}

We began evaluating the mechanism implicated in the reduction of MCF-7 cell viability by determining cell death following treatment with equol and 4-OHT. These compounds induced MCF-7 death after $72 \mathrm{~h}$ of treatment (Figure 2A). Interestingly, their combination enhanced cell death in an additive manner $\left(P_{[\text {[Equol+4-OHT] }}\right.$ vs. 4 -OHT $=0.028 ; P_{[E q u o l+4-O H T]}$ vs. Equol $\left.=0.023\right)$. 

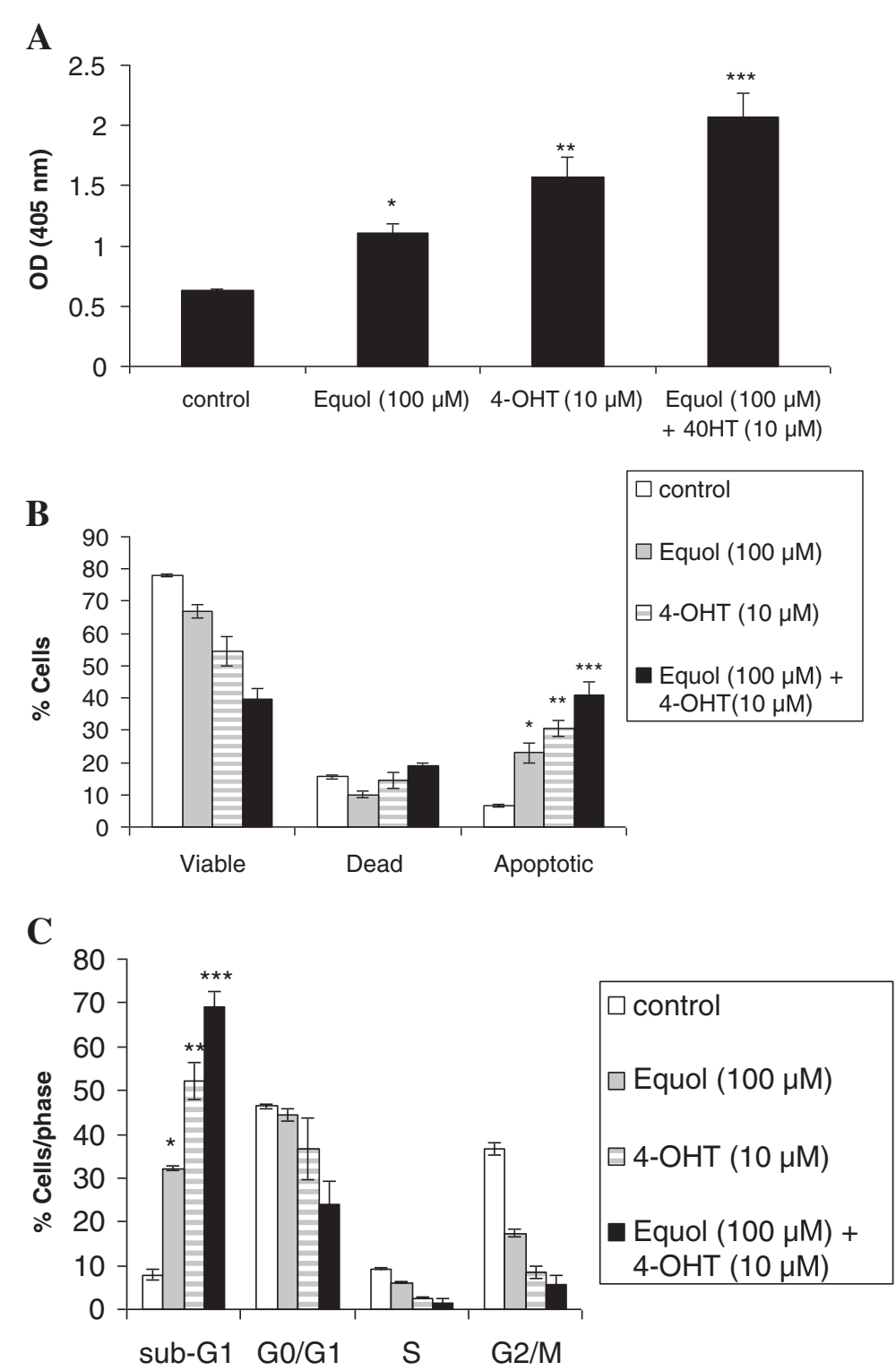

Figure 2 Effect of equol and 4-OHT on cell death (A), apoptosis (B) and cell cycle distribution (C). For the determination of cell death (A), MCF-7 cells were seeded in 96-well plates $\left(3 \times 10^{3}\right.$ cells/well). Upon attachment cells were treated with equol $(100 \mu \mathrm{M})$ and/or 4-OHT (100 $\left.\mu \mathrm{M}\right)$. After 72 hours, cell death was evaluated using the Cell Death ELISA. The OD reading at $405 \mathrm{~nm}$ was proportional to the number of nucleosomes released in the cell lysates of the cells. The data are expressed as OD $(405 \mathrm{~nm})$ in comparison to the vehicle- treated control group. Each group was repeated in quadruplicates. ${ }^{*} P_{\text {Equol vs control }}=0.023 ;{ }^{*} P_{4-\mathrm{OHT}}$ vs control $=0.032 ;{ }^{* * *} P_{\text {[Equol+4-OHT }}$ vs control $=0.016$. (B) Effect of equol and 4-OHT on MCF-7 cell apoptosis using annexin-V Alexa Fluor ${ }^{\circledR} 488 /$ PI staining. Cells were plated in 60-mm plates and treated with equol (100 $\left.\mu \mathrm{M}\right)$ and 4-OHT $(10 \mu \mathrm{M})$ for $72 \mathrm{~h}$. Cell viability, death and apoptosis were evaluated using the Tali ${ }^{\mathrm{TM}}$ apoptosis kit and the Tali ${ }^{\mathrm{TM}}$ Image-based Cytometer. Each experimental group was repeated in triplicate. Bars correspond to the standard error of mean (SEM). ${ }^{*} P_{\text {Equol vs control }}=0.032 ;{ }^{* *} P_{4-\mathrm{OHT}}$ vs control $=0.011$; *** $P_{\text {[Equol }+4-\mathrm{OHT} \text { v v control }}=0.013$. (C) Effect of equol and 4-OHT on cell cycle distribution using PI staining. MCF-7 cells were treated with equol $(100 \mu \mathrm{M})$ and 4-OHT $(10 \mu \mathrm{M})$ for $72 \mathrm{~h}$. Cell cycle distribution was evaluated using PI staining for 15 min at $37^{\circ} \mathrm{C}$. Sample analysis was performed using the Guava EasyCyte ${ }^{\mathrm{TM}}$ flow cytometer and the GuavaSoft analysis software. Each experimental group was repeated in triplicate. Bars correspond to the standard error of mean (SEM). * $P_{\text {Equol vs control }}=0.0025 ;{ }^{* *} P_{4-\mathrm{OHT}}$ vs control $=0.026 ;{ }^{* * *} P_{\text {[Equol+4-OHT] vs control }}=0.0037$.

To examine whether cell death was mediated through apoptosis, cells were stained with annexin-V/PI following treatment with equol and 4-OHT. Each compound produced a substantial increase in the percentage of apoptotic cells (Figure 2B). The combination of equol and 4-OHT had an additive effect on cell apoptosis $\left(P_{[E q u o l+4-O H T]} v s\right.$.

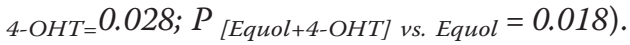

The effects of equol and tamoxifen on cell cycle progression were also determined using flow cytometry. Even though no substantial changes were evident in cell 
cycle distribution from 6-48 h of treatment (data not shown), significant increase in the sub- $G_{1}$ phase, which is indicative of apoptosis, was observed at $72 \mathrm{~h}$, accompanied by a marked reduction in the percentage of cells in the $G_{0} / G_{1}, S$ and $G_{2} / M$ phases (Figure $2 C$ ). These results show that $68.9 \pm 3.6 \%$ of the cells treated with the equol/4-OHT combination were in the sub-G $\mathrm{G}_{1}$ phase, which is significantly higher than the corresponding percentage of equol-treated cells $(32.1 \pm 0.5 \%), 4-\mathrm{OHT}$ treated cells $(52.1 \pm 4.2 \%)$ or vehicle control treated cells $(7.8 \pm 1.1 \%)(P=0.0037$; Figure $2 C)$. Taken together, these results indicate that these agents do not induce cell cycle arrest, and that their combination is more effective in activating apoptosis than each compound alone. This is consistent with our previous data, demonstrating that equol and 4-OHT do not increase p53 and p21 expression, which is up-regulated in cells undergoing $\mathrm{G}_{1}$ arrest (data not shown).

\section{Z-VAD-FMK inhibits equol and 4-OHT mediated apoptosis} To elucidate the precise pathways involved in equoland 4-OHT-induced apoptosis, cells were treated with the pan-caspase inhibitor Z-VAD-FMK in combination with equol and/or 4-OHT and apoptosis was evaluated using annexin-V/PI staining. Z-VAD-FMK significantly inhibited equol- and 4-OHT-induced apoptosis, indicating activation of the caspase-dependent pathway by these compounds (Figure 3). However, the inhibition was not complete, suggesting that caspase-independent mechanisms may be implicated in addition to the caspase dependent mechanisms.

\section{Equol and 4-OHT induce PARP and $\boldsymbol{\alpha}$-fodrin proteolysis}

The apoptotic mechanisms involved in the death response to equol and 4-OHT were further characterized by monitoring PARP and $\alpha$-fodrin expression using western blotting. PARP and $\alpha$-fodrin are known substrates cleaved by the effector caspases- 3 and -7 , which are activated in apoptotic cells $[43,44]$. PARP and $\alpha$-fodrin proteolysis was evident with equol or 4-OHT treatment and was significantly enhanced by their combination (Figure 4A). This effect was prevented to a large extent by Z-VAD-FMK (Figure 4A), reconfirming that equol- and 4-OHT activate caspase-mediated apoptosis.

\section{Equol and 4-OHT induce apoptosis via the intrinsic pathway}

Based on our previous results suggesting activation of caspase-dependent apoptosis by equol and 4-OHT, we examined their effect on caspase expression and activation. To distinguish between the intrinsic and the extrinsic apoptotic pathways, we investigated the effect of equol and 4-OHT on the initiator caspases -8 and -9 and the effector caspases -6 and -7 . Equol and 4-OHT

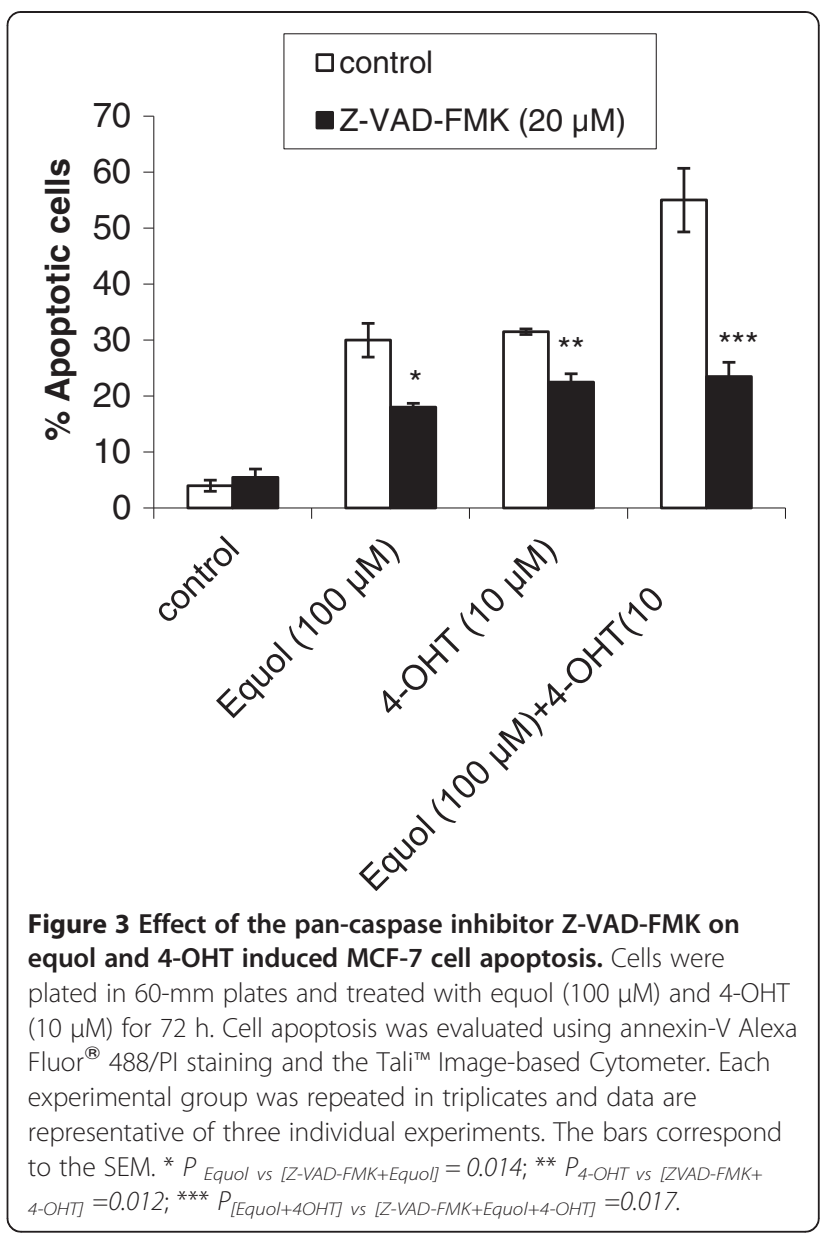

induced a pronounced pro-caspase- 7 and pro-caspase- 9 cleavage and activation, which was greatly enhanced by their combination (Figure 4B). In contrast, caspase-8 and caspase- 6 remained unaffected by these treatments (Figure 4B), indicating that these compounds act mainly through the intrinsic apoptotic pathway.

\section{The combination of equol and 4-OHT promotes cytochrome-c release and reduction of bcl-2 expression}

The key event causing caspase- 9 cleavage, and thus activation of the intrinsic apoptotic pathway, is cytochrome-c release from the mitochondria to the cytosol [45]. Therefore, we explored the effect of equol and tamoxifen on cytochrome-c expression and localization. The combination of equol and 4-OHT induced a substantial cytochrome-c release from the mitochondria to the cytosol of MCF-7 cells (Figure 5) which was not detected in cells treated with equol or 4-OHT alone, thus confirming the activation of the intrinsic apoptotic pathway.

To complete the picture, we investigated the effect of the two compounds and their combination on the expression of the anti-apoptotic protein bcl-2 and the proapoptotic protein bax [46]. Bcl-2 and bax are proteins 


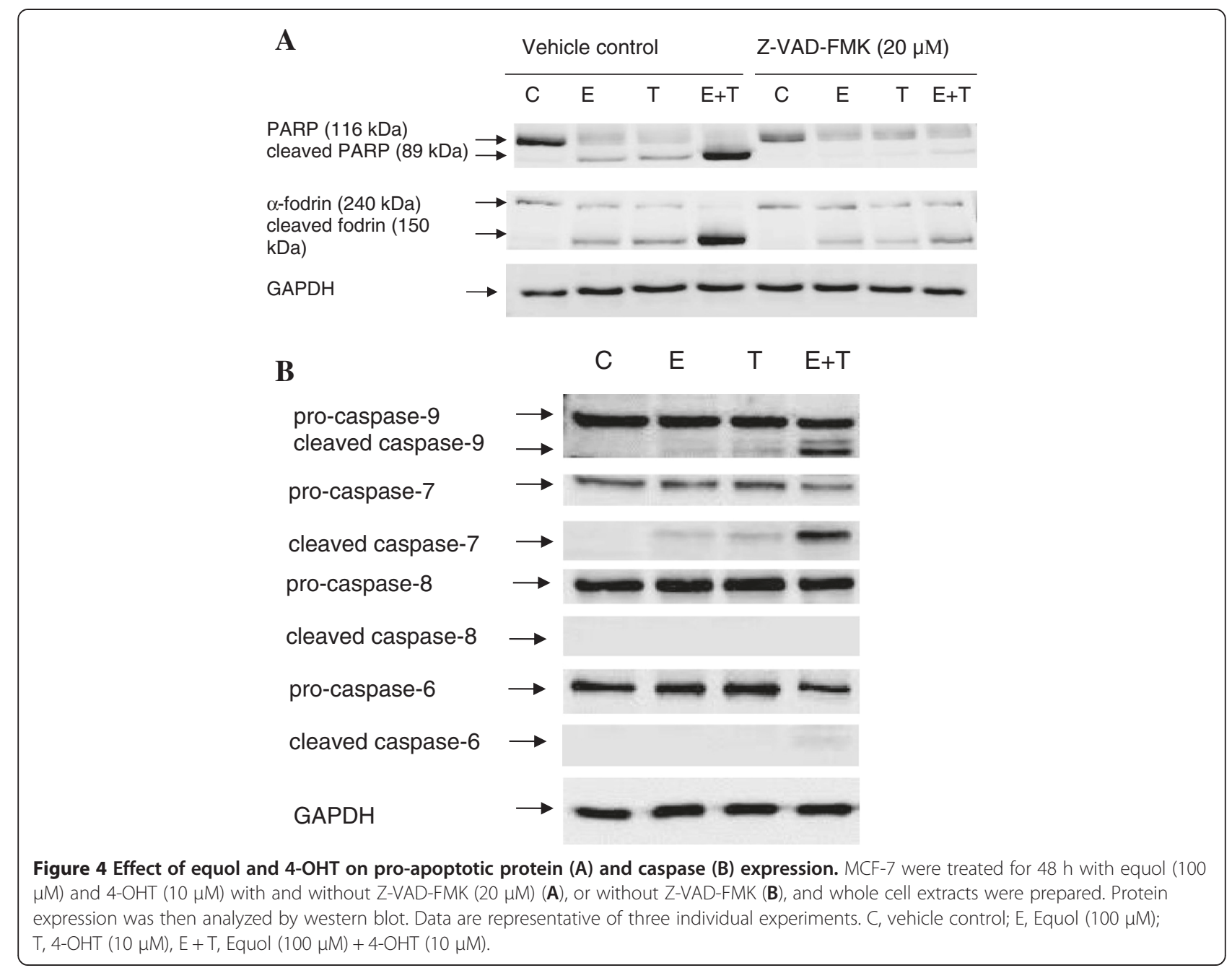

that can prevent or facilitate cytochrome-c release from the mitochondria respectively, thus inhibiting or promoting apoptosis [47]. The bcl-2:bax ratio is important in determining whether a cell will undergo apoptosis or survive [47]. We found that equol and 4-OHT induced a time-dependent reduction in the total levels of bcl-2 in MCF-7 cells, whereas they did not affect bax expression (Figure 6). The combination of equol and tamoxifen had an additive effect in the reduction of bcl-2 expression, which was more evident at $72 \mathrm{~h}$ (Figure 6). Equol and 4-OHT did not affect bcl-2 or bax expression at $24 \mathrm{~h}$ of treatment (data not shown). Therefore, equol and 4-OHT induce a time-dependent reduction of the bcl-2:bax ratio, promoting in this way cytochrome-c release and activation of the intrinsic apoptotic pathway.

\section{Discussion}

In this study, we evaluated the individual and combined effects of equol and 4-OHT, the bioactive metabolite of tamoxifen, in the ER positive MCF-7 breast cancer cells. Our findings show for the first time that equol not only does not abolish the anti-tumor effects of tamoxifen, but instead it induces apoptosis and significantly enhances tamoxifen's pro-apoptotic effects in these cells (Figure 1A$\mathrm{C}$ and Figure 2A-C). Moreover, the pan-caspase inhibitor Z-VAD-FMK significantly inhibited equol- and tamoxifeninduced apoptosis (Figure 3), suggesting that these compounds activate the caspase-mediated apoptotic pathway. However, the inhibition was not complete, suggesting that caspase-independent mechanisms may also be involved in equol and tamoxifen induced apoptosis. Previous studies support our findings showing that equol inhibits MCF-7 proliferation and induces caspase-mediated apoptosis in ER negative breast cancer cells and rat mammary tumors $[8,48,49]$. With respect to tamoxifen, previous studies provide evidence that tamoxifen induces caspase-dependent apoptosis in MCF-7 and other types of cancer cells [30,32,50-53]. Even though high concentrations of equol $(100 \mu \mathrm{M})$ were required to activate MCF-7 apoptosis, which are not physiologically achievable in human plasma due to metabolic conversion of the active aglycone equol to the inactive conjugated form [54], our results may find 


\section{Mitochondrial Cytosolic extract

$\begin{array}{llll}C & E & T & E+T\end{array}$

$\begin{array}{llll}C & E & T & E+T\end{array}$ \\ cytochrome-c \\ COX-4

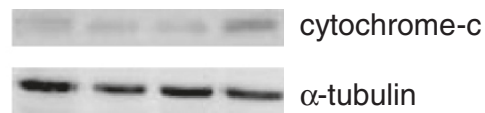

Figure 5 Effect of equol and 4-OHT on cytochrome-c expression. MCF-7 were treated for $48 \mathrm{~h}$ with equol (100 $\mu \mathrm{M})$ and 4-OHT (10 $\mu \mathrm{M})$ and mitochondrial and cytosolic extracts were prepared. Protein expression was then analyzed by western blot. Data are representative of three

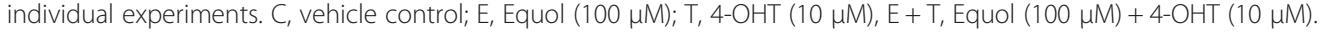

applications in targeted immunotherapies, which may enable maximal delivery of equol into the cancer cells. This strategy was previously used successfully for genistein, which was immunoconjugated with a monoclonal antibody and targeted to a B cell-specific receptor for treatment of an animal model of B-cell precursor leukemia [55].

To fully explore the apoptotic pathway activated by equol and tamoxifen, we investigated their effects on key proteins involved in apoptosis, such PARP, $\alpha$-fodrin and caspases $-6,-7,-8$ and -9 . Caspase- 9 is part of the intrinsic (mitochondrial) apoptotic pathway and is activated by cytochrome-c release from the mitochondria, whereas caspase- 8 is part of the extrinsic apoptotic pathway activated by external signals through the death receptors [45]. Active caspase -9 and caspase- 8 in turn induce cleavage and activation of the effector caspases $-3,-6$ and $-7[43,45,56,57]$, which subsequently cleave nuclear and cytosolic targets, such as PARP and $\alpha$-fodrin, resulting in cell destruction [43,44]. Since MCF-7 cells are deficient of functional caspase-3, the effector caspase-7 is responsible for apoptosis in these cells [58-60]. Our experiments show that equol and 4-OHT induce PARP and $\alpha$-fodrin proteolysis, which was significantly enhanced by their combination and partially inhibited by the pan-caspase inhibitor Z-VAD-FMK (Figure 4A), suggesting that additional proteases besides caspases may be involved in equol- and tamoxifen-induced apoptosis. Furthermore, the combination of equol and tamoxifen induced a pronounced caspase- 9 and caspase- 7 cleavage accompanied with cytochrome-c release into the cytosol, without affecting caspases- 6 and -8 (Figure 4B and Figure 5). Treatment with either equol or tamoxifen, on the other hand, had a lesser effect on caspase- 9 and caspase- 7 cleavage associated with a trivial effect on cytochrome-c release from the mitochondria into the cytosol. Consequently, the combination of equol and tamoxifen is significantly more potent in inducing MCF-7 cell apoptosis than each compound alone. Therefore, our data suggest that equol and tamoxifen activate the intrinsic apoptotic pathway. Previous studies support our findings as they have shown activation of the intrinsic apoptotic pathway in MCF-7 cells by tamoxifen and daidzein [2,29-31,51,61,62]. Moreover, equol and tamoxifen induced a time-dependent reduction in blc-2 expression and hence the bcl-2:bax ratio, which was further reduced by the combination of the two compounds (Figure 6). Decreased bcl-2 expression was observed in several cancer cell types treated with tamoxifen and daidzein $[14,63,64]$ and in equol-induced apoptosis in mammary carcinomas $[14,48]$.

\section{Conclusions}

In conclusion, this study suggests that equol induces MCF-7 cell apoptosis and enhances tamoxifen's proapoptotic effect via activation of the intrinsic apoptotic

\section{$48 \mathrm{~h}$} $72 \mathrm{~h}$

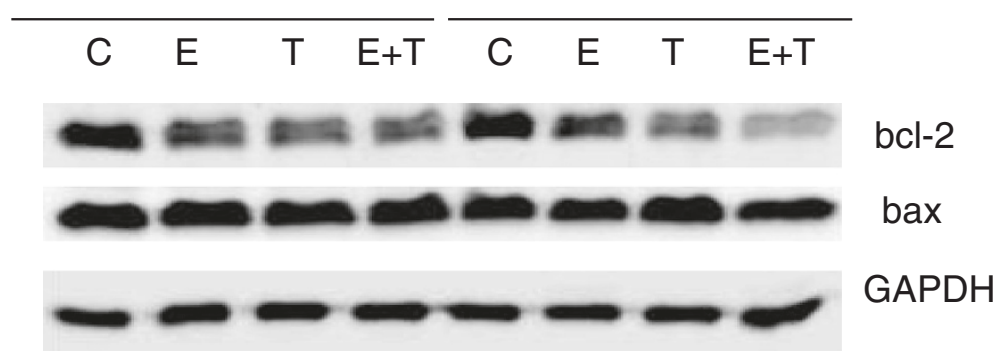

Figure 6 Effect of equol and 4-OHT on bcl-2 and bax expression. MCF-7 were treated for 48 and 72 h with equol (100 $\mu \mathrm{M})$ and 4-OHT (10 $\mu \mathrm{M})$ and whole cell extracts were prepared. Protein expression was then analyzed by western blot using anti-bcl-2 and anti-bax polyclonal antibodies. Data are representative of three individual experiments. C, vehicle control; E, Equol $(100 \mu \mathrm{M}) ; \mathrm{T}, 4-\mathrm{OHT}(10 \mu \mathrm{M}), \mathrm{E}+\mathrm{T}$, Equol $(100 \mathrm{\mu M})+$ 4-OHT $(10 \mu \mathrm{M})$. 
pathway. The significance of our findings is that women with ER-positive early-stage breast cancer, undergoing tamoxifen adjuvant treatment, may be further benefitted by co-treatment with pharmacological doses of equol. Our results also suggest that "equol producers" may be at lower risk of developing breast cancer due to the apoptotic action of equol against ER positive breast cancer cells. Future clinical trials designed to determine the safety and efficacy of equol in adjuvant hormonal therapy against breast cancer are warranted.

\section{Abbreviations}

BCA: Bicinchronic acid; COX-4: Cyclo-oxygenase-4; DMBA: 6,12 - dimethylbenz [a]anthracene; ELISA: Enzyme-linked immunosorbent assay; ER: Estrogen receptor; FBS: Fetal bovine serum; GAPDH: Glyceraldehyde 3-phosphate dehydrogenase; IgG: Immunoglobulin G; MTT: Monotetrazolium; 4-OHT: 4-hydroxy-tamoxifen; PARP: Poly (ADP ribose) polymerase; PI: Propidium iodide; SERM: Selective estrogen receptor modulator.

\section{Competing interests}

The authors declare that they have no competing interests.

\section{Authors' contributions}

CC carried out all the experiments included in this manuscript and participated in the design, data acquisition, analysis and interpretation. CAP provided assistance with some of the experiments and valuable feedback. AIC participated in the experimental design, data analysis and interpretation. Both CC and AIC participated in drafting and critically revising the manuscript. All authors read and approved the final manuscript.

\section{Acknowledgements}

The authors wish to thank Dr Paul Costeas, Dr Laoura Koumas and Dr Carsten Lederer for their help with flow cytometric analysis. This work was supported by the Cyprus Research Promotion Foundation grant YGEIA/ TROFH/0308(BE).

\section{Study design}

The role of equol, tamoxifen and their combination in breast cancer treatment.

Received: 21 December 2012 Accepted: 30 April 2013

Published: 15 May 2013

\section{References}

1. McPherson $K$, Steel CM, Dixon JM: ABC of breast diseases. Breast cancerepidemiology, risk factors, and genetics. BMJ 2000, 321(7261):624-628.

2. Jin S, Zhang QY, Kang XM, Wang JX, Zhao WH: Daidzein induces MCF-7 breast cancer cell apoptosis via the mitochondrial pathway. Ann Oncol 2010, 21(2):263-268.

3. Chan K, Morris GJ: Chemoprevention of breast cancer for women at high risk. Semin Oncol 2006, 33(6):642-646.

4. Jemal A, Thomas A, Murray T, Thun M: Cancer statistics, 2002. CA Cancer Clin 2002, 52(1):23-47.

5. Adlercreutz H: Phyto-oestrogens and cancer. Lancet Oncol 2002, 3(6):364-373.

6. Mitchell JH, Gardner PT, MCPhail DB, Morrice PC, Collins AR, Duthie GG: Antioxidant efficacy of phytoestrogens in chemical and biological model systems. Arch Biochem Biophys 1998, 360(1):142-148.

7. Arora A, Nair MG, Strasburg GM: Antioxidant activities of isoflavones and their biological metabolites in a liposomal system. Arch Biochem Biophys 1998, 356(2):133-141.

8. Choi EJ, Ahn WS, Bae SM: Equol induces apoptosis through cytochrome c-mediated caspases cascade in human breast cancer MDA-MB-453 cells. Chem Biol Interact 2009, 177(1):7-11.

9. Lampe JW, Karr SC, Hutchins AM, Slavin JL: Urinary equol excretion with a soy challenge: influence of habitual diet. Proc Soc Exp Biol Med 1998, 217(3):335-339.
10. Setchell KD, Brown NM, Lydeking-Olsen E: The clinical importance of the metabolite equol-a clue to the effectiveness of soy and its isoflavones. J Nutr 2002, 132(12):3577-3584.

11. Treeck O, Juhasz-Boess I, Lattrich C, Horn F, Goerse R, Ortmann O: Effects of exon-deleted estrogen receptor beta transcript variants on growth, apoptosis and gene expression of human breast cancer cell lines. Breast Cancer Res Treat 2008, 110(3):507-520.

12. Treeck $O$, Lattrich $C$, Springwald A, Ortmann O: Estrogen receptor beta exerts growth-inhibitory effects on human mammary epithelial cells. Breast Cancer Res Treat 2010, 120(3):557-565.

13. Paruthiyil S, Parmar H, Kerekatte V, Cunha GR, Firestone GL, Leitman DC: Estrogen receptor beta inhibits human breast cancer cell proliferation and tumor formation by causing a G2 cell cycle arrest. Cancer Res 2004 64(1):423-428.

14. Choi EJ, Kim T: Equol induced apoptosis via cell cycle arrest in human breast cancer MDA-MB-453 but not MCF-7 cells. Mol Med Report 2008, 1(2):239-244.

15. Magee PJ, Raschke M, Steiner C, Duffin JG, Pool-Zobel BL, Jokela T, Wahala $K$, Rowland IR: Equol: a comparison of the effects of the racemic compound with that of the purified S-enantiomer on the growth, invasion, and DNA integrity of breast and prostate cells in vitro. Nutr Cancer 2006, 54(2):232-242.

16. Schmitt E, Dekant W, Stopper H: Assaying the estrogenicity of phytoestrogens in cells of different estrogen sensitive tissues. Toxicol In Vitro 2001, 15(4-5):433-439.

17. Sathyamoorthy $N$, Wang $\Pi$ : Differential effects of dietary phytooestrogens daidzein and equol on human breast cancer MCF-7 cells. Eur J Cancer 1997, 33(14):2384-2389.

18. Tonetti DA, Zhang Y, Zhao H, Lim SB, Constantinou Al: The effect of the phytoestrogens genistein, daidzein, and equol on the growth of tamoxifen-resistant T47D/PKC alpha. Nutr Cancer 2007, 58(2):222-229.

19. Lampe JW: Emerging research on equol and cancer. J Nutr 2010, 140(7):1369S-1372S.

20. Kandaswami C, Lee LT, Lee PP, Hwang JJ, Ke FC, Huang YT, Lee MT: The antitumor activities of flavonoids. In Vivo 2005, 19(5):895-909.

21. Le Marchand $L$ : Cancer preventive effects of flavonoids-a review. Biomed Pharmacother 2002, 56(6):296-301.

22. Ren W, Qiao Z, Wang H, Zhu L, Zhang L: Flavonoids: promising anticancer agents. Med Res Rev 2003, 23(4):519-534.

23. de Lemos ML: Effects of soy phytoestrogens genistein and daidzein on breast cancer growth. Ann Pharmacother 2001, 35(9):1118-1121.

24. Gercel-Taylor C, Feitelson AK, Taylor DD: Inhibitory effect of genistein and daidzein on ovarian cancer cell growth. Anticancer Res 2004 24(2B):795-800.

25. Guo JM, Xiao BX, Liu DH, Grant M, Zhang S, Lai YF, Guo YB, Liu Q: Biphasic effect of daidzein on cell growth of human colon cancer cells. Food Chem Toxicol 2004, 42(10):1641-1646.

26. Fisher B, Costantino JP, Wickerham DL, Redmond CK, Kavanah M, Cronin WM, Vogel V, Robidoux A, Dimitrov N, Atkins J, et al: Tamoxifen for prevention of breast cancer: report of the National Surgical Adjuvant Breast and Bowel Project P-1 Study. J Nat/ Cancer Inst 1998, 90(18):1371-1388.

27. McKeon VA: The breast cancer prevention trial: should women at risk take tamoxifen? J Obstet Gynecol Neonatal Nurs 1999, 28(6 Suppl 1):34-38.

28. Radmacher MD, Simon R: Estimation of tamoxifen's efficacy for preventing the formation and growth of breast tumors. J Nat/ Cancer Inst 2000, 92(1):48-53.

29. Kallio A, Zheng A, Dahllund J, Heiskanen KM, Harkonen P: Role of mitochondria in tamoxifen-induced rapid death of MCF-7 breast cancer cells. Apoptosis 2005, 10(6):1395-1410.

30. Mandlekar S, Hebbar V, Christov K, Kong AN: Pharmacodynamics of tamoxifen and its 4-hydroxy and N-desmethyl metabolites: activation of caspases and induction of apoptosis in rat mammary tumors and in human breast cancer cell lines. Cancer Res 2000, 60(23):6601-6606.

31. Mandlekar S, Kong AN: Mechanisms of tamoxifen-induced apoptosis. Apoptosis 2001, 6(6):469-477.

32. Salami S, Karami-Tehrani F: Biochemical studies of apoptosis induced by tamoxifen in estrogen receptor positive and negative breast cancer cell lines. Clin Biochem 2003, 36(4):247-253.

33. Couldwell WT, Hinton DR, He S, Chen TC, Sebat I, Weiss MH, Law RE: Protein kinase $C$ inhibitors induce apoptosis in human malignant glioma cell lines. FEBS Lett 1994, 345(1):43-46. 
34. Gelmann EP: Tamoxifen for the treatment of malignancies other than breast and endometrial carcinoma. Semin Oncol 1997, 24(1 Suppl 1):S1-S65. S61-70.

35. Constantinou Al, Lantvit D, Hawthorne M, Xu X, van Breemen RB, Pezzuto $J M$ : Chemopreventive effects of soy protein and purified soy isoflavones on DMBA-induced mammary tumors in female Sprague-Dawley rats. Nutr Cancer 2001, 41(1-2):75-81.

36. Constantinou Al, Mehta RG, Vaughan A: Inhibition of N-methyl-Nnitrosourea-induced mammary tumors in rats by the soybean isoflavones. Anticancer Res 1996, 16(6A):3293-3298.

37. Constantinou Al, White BE, Tonetti D, Yang Y, Liang W, Li W, van Breemen RB: The soy isoflavone daidzein improves the capacity of tamoxifen to prevent mammary tumours. Eur J Cancer 2005, 41(4):647-654.

38. Hwang J, Wang J, Morazzoni P, Hodis HN, Sevanian A: The phytoestrogen equol increases nitric oxide availability by inhibiting superoxide production: an antioxidant mechanism for cell-mediated LDL modification. Free Radic Biol Med 2003, 34(10):1271-1282.

39. Rufer CE, Kulling SE: Antioxidant activity of isoflavones and their major metabolites using different in vitro assays. J Agric Food Chem 2006, 54(8):2926-2931.

40. Pink JJ, Bilimoria MM, Assikis J, Jordan VC: Irreversible loss of the oestrogen receptor in T47D breast cancer cells following prolonged oestrogen deprivation. Br J Cancer 1996, 74(8):1227-1236.

41. Mosmann T: Rapid colorimetric assay for cellular growth and survival: application to proliferation and cytotoxicity assays. J Immunol Methods 1983, 65(1-2):55-63.

42. Batsi C, Markopoulou S, Kontargiris E, Charalambous C, Thomas C, Christoforidis S, Kanavaros P, Constantinou Al, Marcu KB, Kolettas E: Bcl-2 blocks 2-methoxyestradiol induced leukemia cell apoptosis by a p27 (Kip1)-dependent G1/S cell cycle arrest in conjunction with NF-kappaB activation. Biochem Pharmacol 2009, 78(1):33-44.

43. Cohen GM: Caspases: the executioners of apoptosis. Biochem J 1997 326(Pt 1):1-16.

44. Wang KK, Posmantur R, Nath R, McGinnis K, Whitton M, Talanian RV, Glantz SB, Morrow JS: Simultaneous degradation of alphall- and betall-spectrin by caspase 3 (CPP32) in apoptotic cells. J Biol Chem 1998, 273(35):22490-22497.

45. Li P, Nijhawan D, Budihardjo I, Srinivasula SM, Ahmad M, Alnemri ES, Wang $X$ : Cytochrome $c$ and dATP-dependent formation of Apaf-1/caspase-9 complex initiates an apoptotic protease cascade. Cell 1997, 91(4):479-489.

46. Reed JC: $\mathrm{BCl}-2$ and the regulation of programmed cell death. $J$ Cell Biol 1994, 124(1-2):1-6.

47. Mohamad N, Gutierrez A, Nunez M, Cocca C, Martin G, Cricco G, Medina V, Rivera E, Bergoc R: Mitochondrial apoptotic pathways. Biocell 2005, 29(2):149-161

48. Choi EJ, Kim GH: Anticancer mechanism of equol in 7,12-dimethylbenz(a) anthracene-treated animals. Int J Oncol 2011, 39(3):747-754.

49. Widyarini S, Husband AJ, Reeve VE: Protective effect of the isoflavonoid equol against hairless mouse skin carcinogenesis induced by UV radiation alone or with a chemical cocarcinogen. Photochem Photobiol 2005, 81(1):32-37.

50. Gaddy VT, Barrett JT, Delk JN, Kallab AM, Porter AG, Schoenlein PV: Mifepristone induces growth arrest, caspase activation, and apoptosis of estrogen receptor-expressing, antiestrogen-resistant breast cancer cells. Clin Cancer Res 2004, 10(15):5215-5225.

51. Nigam M, Ranjan V, Srivastava S, Sharma R, Balapure AK: Centchroman induces G0/G1 arrest and caspase-dependent apoptosis involving mitochondrial membrane depolarization in MCF-7 and MDA MB-231 human breast cancer cells. Life Sci 2008, 82(11-12):577-590.

52. Otto AM, Paddenberg R, Schubert S, Mannherz HG: Cell-cycle arrest, micronucleus formation, and cell death in growth inhibition of MCF-7 breast cancer cells by tamoxifen and cisplatin. J Cancer Res Clin Oncol 1996, 122(10):603-612.

53. Sutherland RL, Hall RE, Taylor IW: Cell proliferation kinetics of MCF-7 human mammary carcinoma cells in culture and effects of tamoxifen on exponentially growing and plateau-phase cells. Cancer Res 1983, 43(9):3998-4006.

54. Allred CD, Twaddle NC, Allred KF, Goeppinger TS, Churchwell MI, Ju YH, Helferich WG, Doerge DR: Soy processing affects metabolism and disposition of dietary isoflavones in ovariectomized BALB/c mice. J Agric Food Chem 2005, 53(22):8542-8550

55. Uckun FM, Evans WE, Forsyth CJ, Waddick KG, Ahlgren LT, Chelstrom LM, Burkhardt A, Bolen J, Myers DE: Biotherapy of B-cell precursor leukemia by targeting genistein to CD19-associated tyrosine kinases. Science 1995, 267(5199):886-891.

56. Boldin MP, Goncharov TM, Goltsev YV, Wallach D: Involvement of MACH, a novel MORT1/FADD-interacting protease, in Fas/APO-1- and TNF receptor-induced cell death. Cell 1996, 85(6):803-815.

57. Muzio M, Chinnaiyan AM, Kischkel FC, O'Rourke K, Shevchenko A, Ni J, Scaffidi C, Bretz JD, Zhang M, Gentz R, et al: FLICE, a novel FADD-homologous ICE/ CED-3-like protease, is recruited to the CD95 (Fas/APO-1) death-inducing signaling complex. Cell 1996, 85(6):817-827.

58. Hu CC, Tang CH, Wang JJ: Caspase activation in response to cytotoxic Rana catesbeiana ribonuclease in MCF-7 cells. FEBS Lett 2001, 503(1):65-68.

59. Janicke RU, Sprengart ML, Wati MR, Porter AG: Caspase-3 is required for DNA fragmentation and morphological changes associated with apoptosis. J Biol Chem 1998, 273(16):9357-9360

60. Waterhouse NJ, Finucane DM, Green DR, Elce JS, Kumar S, Alnemri ES, Litwack G, Khanna K, Lavin MF, Watters DJ: Calpain activation is upstream of caspases in radiation-induced apoptosis. Cell Death Differ 1998, 5(12):1051-1061.

61. Berstein LM, Yue W, Wang JP, Santen RJ: Isolated and combined action of tamoxifen and metformin in wild-type, tamoxifen-resistant, and estrogendeprived MCF-7 cells. Breast Cancer Res Treat 2011, 128(1):109-117.

62. Nazarewicz RR, Zenebe WJ, Parihar A, Larson SK, Alidema E, Choi J, Ghafourifar P: Tamoxifen induces oxidative stress and mitochondrial apoptosis via stimulating mitochondrial nitric oxide synthase. Cancer Res 2007, 67(3):1282-1290.

63. Fattman CL, An B, Sussman L, Dou QP: p53-independent dephosphorylation and cleavage of retinoblastoma protein during tamoxifen-induced apoptosis in human breast carcinoma cells. Cancer Lett 1998, 130(1-2):103-113.

64. Ko YM, Wu TY, Wu YC, Chang FR, Guh JY, Chuang LY: Annonacin induces cell cycle-dependent growth arrest and apoptosis in estrogen receptoralpha-related pathways in MCF-7 cells. J Ethnopharmacol 2011, 137(3):1283-1290.

doi:10.1186/1471-2407-13-238

Cite this article as: Charalambous et al.: Equol enhances tamoxifen's anti-tumor activity by induction of caspase-mediated apoptosis in MCF-7 breast cancer cells. BMC Cancer 2013 13:238.

\section{Submit your next manuscript to BioMed Central and take full advantage of:}

- Convenient online submission

- Thorough peer review

- No space constraints or color figure charges

- Immediate publication on acceptance

- Inclusion in PubMed, CAS, Scopus and Google Scholar

- Research which is freely available for redistribution 